\title{
Novitates neocaledonicae V: Eugenia plurinervia N. Snow, Munzinger \& Callm. (Myrtaceae), a new threatened species with distinct leaves
}

\author{
Neil Snow, Jérôme Munzinger \& Martin W. Callmander
}

\begin{abstract}
SNOW, N., J. MUNZINGER \& M.W. CALLMANDER (2016). Novitates neocaledonicae V: Eugenia plurinervia N. Snow, Munzinger \& Callm. (Myrtaceae), a new threatened species with distinct leaves. Candollea 71:211-215. In English, English and French abstracts. DOI : http://dx.doi. org/10.15553/c2016v712a7

The new species Eugenia plurinervia N. Snow, Munzinger \& Callm. (Myrtaceae) is proposed for New Caledonia. It is easily diagnosed from other Eugenia L. species by its typically three prominent palmately radiating secondary veins arising from each side of the midvein near the base (or lower third) of the leaf, and densely punctate blades. The new species is only known from c. 660 individuals at a single location in north-western main island Grande Terre and assigned a preliminary conservation status of "Critically Endangered" following IUCN Red List Categories and Criteria.
\end{abstract}

\section{Résumé}

SNOW, N., J. MUNZINGER \& M.W. CALLMANDER (2016). Novitates neocaledonicae V: Eugenia plurinervia N. Snow, Munzinger \& Callm. (Myrtaceae), une nouvelle espèce menacée à feuilles particulières. Candollea 71:211-215. En anglais, résumés anglais et français. DOI: http://dx.doi. org/10.15553/c2016v712a7

La nouvelle espèce Eugenia plurinervia N. Snow, Munzinger \& Callm. (Myrtaceae) est proposée pour la NouvelleCalédonie. Elle se distingue facilement des autres espèces du genre Eugenia L. par ses trois nervures secondaires palmées, proéminentes, rayonnantes depuis près de la base (ou le tiers inférieur de la feuille) de chaque côté de la veine médiane et ses limbes densément ponctués. La nouvelle espèce n’est connue que d'environ 660 individus dans une seule localité dans le nord-ouest de la Grande Terre et est provisoirement considérée comme «En Danger Critique» selon les Catégories et Critères de l'UICN.

\section{Keywords}

MYRTACEAE - Eugenia - New Caledonia - New species - Systematics - Conservation

\footnotetext{
Addresses of the authors:

NS: T.M. Sperry Herbarium, Department of Biology, Pittsburg State University, 1701 S. Broadway, Pittsburg, Kansas 66762, U.S.A. E-mail: nsnow@pittstate.edu JM: Institut de Recherche pour le Développement - Botanique et modélisation de l'architecture des plantes et des végétations (AMAP), 34000 Montpellier, France MWC: Conservatoire et Jardin botaniques de la Ville de Genève, C.P. 60, 1292 Chambésy, Switzerland.
} 


\section{Introduction}

Current data suggest Myrtaceae are the most diverse family of vascular plants in New Caledonia and that Eugenia L. is among the five richest genera (IBAnez et al., 2014; Morat et al., 2012). A brief overview of Eugenia globally and more specifically for New Caledonia was recently provided (SNOw et al., 2016), and as presently understood the genus comprises approximately thirty-six species in New Caledonia, counting the one newly described here.

We here propose a new species of Eugenia that is easily recognizable by its key diagnostic traits, and which has been the focus of recent intensive field surveys. In addition to its diagnosis and description, we provide images of living material and a detailed map of its occurrence on Grande Terre, and include conservation assessments following IUCN Red List Categories and Criteria (IUCN, 2012). The description is based on living material, field observations, digital images of living specimens, herbarium specimens, and material preserved in spirits.

Eugenia plurinervia N. Snow, Munzinger \& Callm., spec. nova (Fig. 1).

Typus : New Caledonia. Prov. Nord: Ouazangou-Taom, Onajiele, 165 m, 2046'43”S 164²7'59”E, 20.III.2016, Munzinger (leg. Scopetra) 7530 (holo- : P [P01069419]!; iso- : G [G00341659]!,MO!, MPU [MPU310532]!, NOU [NOU054468]!, NSW!, P [P01069420]!)

Differing from other species of Eugenia L. in New Caledonia by the combination of typically 3 prominent palmately radiating secondary nerves arising from each side of the midnerve near its base (or lower third) of the leaf blade and its dense and prominent punctate glands.

Loosely branched, erect to spreading shrubs, 1-1.5(-3) m; stem up to $6.5 \mathrm{~cm}$ in diam. at base; bark cream or grayish, flaking or peeling irregularly, often in larger patches; herbage glabrous except where noted; branchlets terete, wingless, smooth but becoming somewhat flaking, oil glands common to dense on emergence but receding with age, emerging maroon but becoming light gray or brown. Leaves 2-3 per node, shortly-petiolate, coriaceous, venation brochidodromous with typically 3 prominent and palmately radiating secondary nerves arising on each side of the midvein from its base (or lower third), discolorous, matte or somewhat glossy above, more or less evenly distributed along branchlets; foliar colleters 5-7 $<0.2 \mathrm{~mm}$ (obscure) and unswollen at base; petioles 1-2 mm, glandular when young. Leaf blades $(11-) 15-18(-24) \times(12-) 13-16(-21) \mathrm{mm}$, mostly very widely ovate to oblate (rarely broadly ovate), base rounded (less commonly truncate), apex rounded (rarely broadly acute), surface flat; adaxial surface sparsely sericeous proximally (trichomes whitish, dibrachiate), midvein slightly projecting or flush (primary and secondary veins protruding when dried), oil glands common to dense and of various sizes (especially prominent if backlit); abaxial surface glabrous, oil glands as above, secondary veins obscure or invisible when fresh but raised prominently when dry; intramarginal vein present but only visible if strongly backlit. Inflorescence a monad, axillary, terminal, or ramiflorous, solitary or paired; pedicel $<2 \mathrm{~mm}$ (but sometimes appearing absent in mature fruit), thick and rigid. Flower buds whitish-green, or sometimes tawny or mottled with maroon, prominently glandular. Bracteoles $2,<0.5 \mathrm{~mm}$, narrowly triangular, stiff and appressed to base of hypanthium, maroon when fresh. Pedicels thick, rigid, $<2 \mathrm{~mm}$; hypanthium c. $1.5 \times 1.5 \mathrm{~mm}$, broadly obconic; flowers (material scant) 4-4.5 mm broad at anthesis; calyx lobes 4, 0.5-1 mm (sometimes barely differentiated from subtending hypanthium), much broader than wide, whitish-greenish (or with small amounts of maroon) and prominently glandular, persistent on mature fruit but if so then typically brownish and withering; petals 4 , c. $2 \times 2 \mathrm{~mm}$, widely ovate to very widely elliptic or oblate, somewhat concave in anthesis, shortly and sparsely ciliate on distal half, densely and prominently glandular, white, texture thin and delicate; staminal disk glabrous; stamens 30-50; filaments to $3 \mathrm{~mm}$, whitish; anthers c. $0.4 \mathrm{~mm}$, globose to subellipsoid, dorsifixed, bearing a single yellowish-green apical gland, whitish but becoming tawny; style c. $3.5 \mathrm{~mm}$, white; stigma terete and apically tapered. Ovary bilocular; placentation axile; ovules 3-4 per locule. Fruit a berry 9-11 $\times$ 9-11 mm (material scant), globose to rounded or subellipsoid to somewhat asymmetrical (including sometimes laterally compressed), yellow-green when immature (especially at base) but becoming green when mature with a soft texture. Seeds usually 1 (but up to 4 ); c. $6.5 \times 4.5 \mathrm{~mm}$, more or less round but laterally compressed; hypanthial wall drying leathery; testa thin but densely fibrous, whitish when fresh; embryo moderately glandular on surface, undifferentiated into evident cotyledons or hypocotyl, yellowish-green when fresh.

Distribution, habitat and phenology. - Eugenia plurinervia is only known from the base of Onajiele hill, near the Ouazangou-Taom massif, in the north-west of Grande-Terre. It grows in shrubby maquis vegetation (JAFFré et al., 2012) on brown hyper-magnesium (ultramafic) soils. It has been observed flowering in December-January, but mostly from February to April and seems to be fruiting throughout the year.

Conservation status. - As of early 2016, the extent of occurrence (EOO) is c. $0.449 \mathrm{~km}^{2}$ and the area of occupancy is $4 \mathrm{~km}^{2}$. A total of c. 660 individuals were located, with the largest subpopulation harboring c. 390 individuals, but collectively we consider these as a single location sensu IUCN 

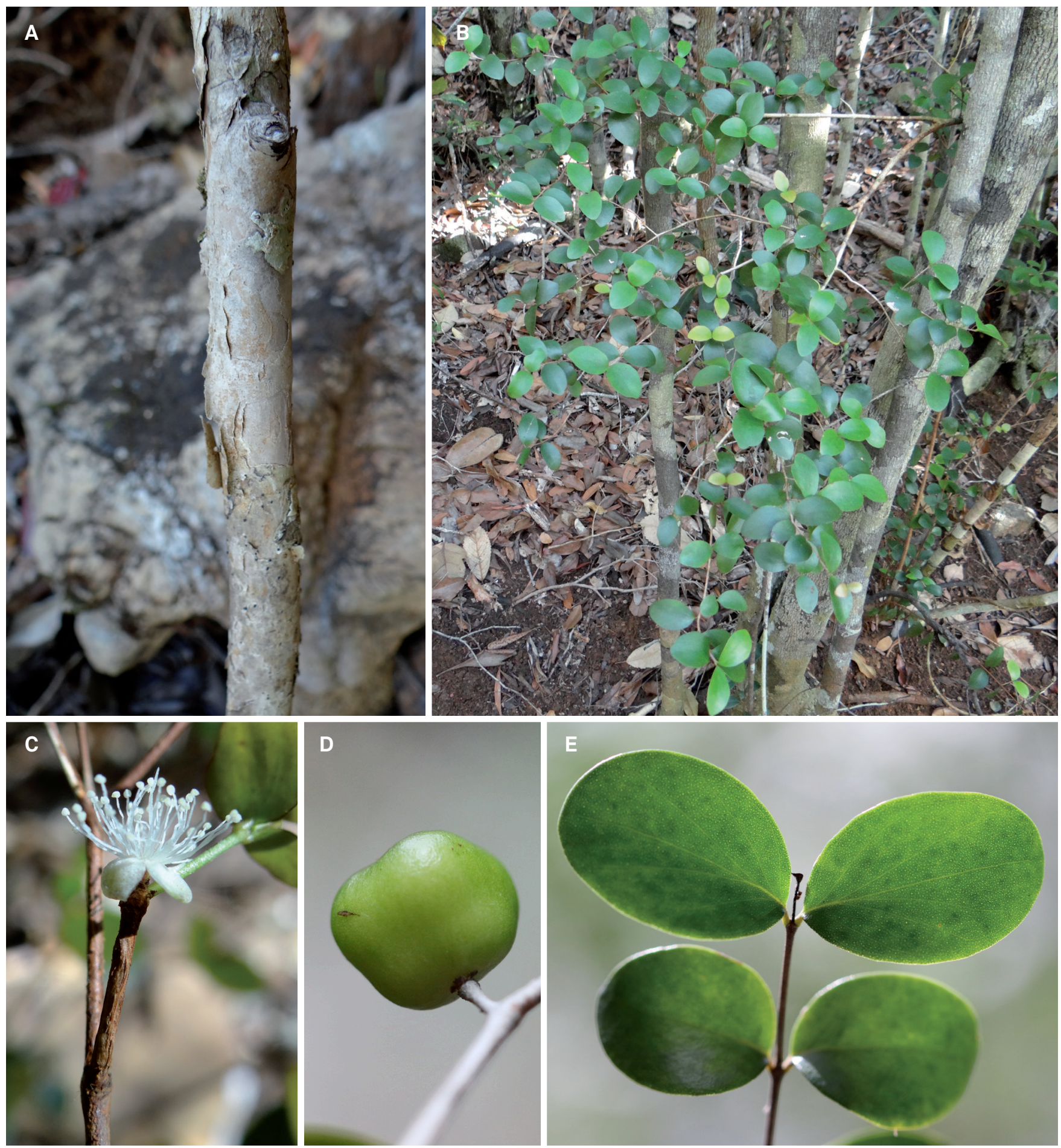

Fig. 1. - Eugenia plurinervia N. Snow, Munzinger \& Callm. A. Main stem with peeling grayish bark;

B. General habit; C. Flower; D. Immature fruit; E. Radiating secondary nerves of the densely punctate leaves.

[Photos: R. Scopetra] 


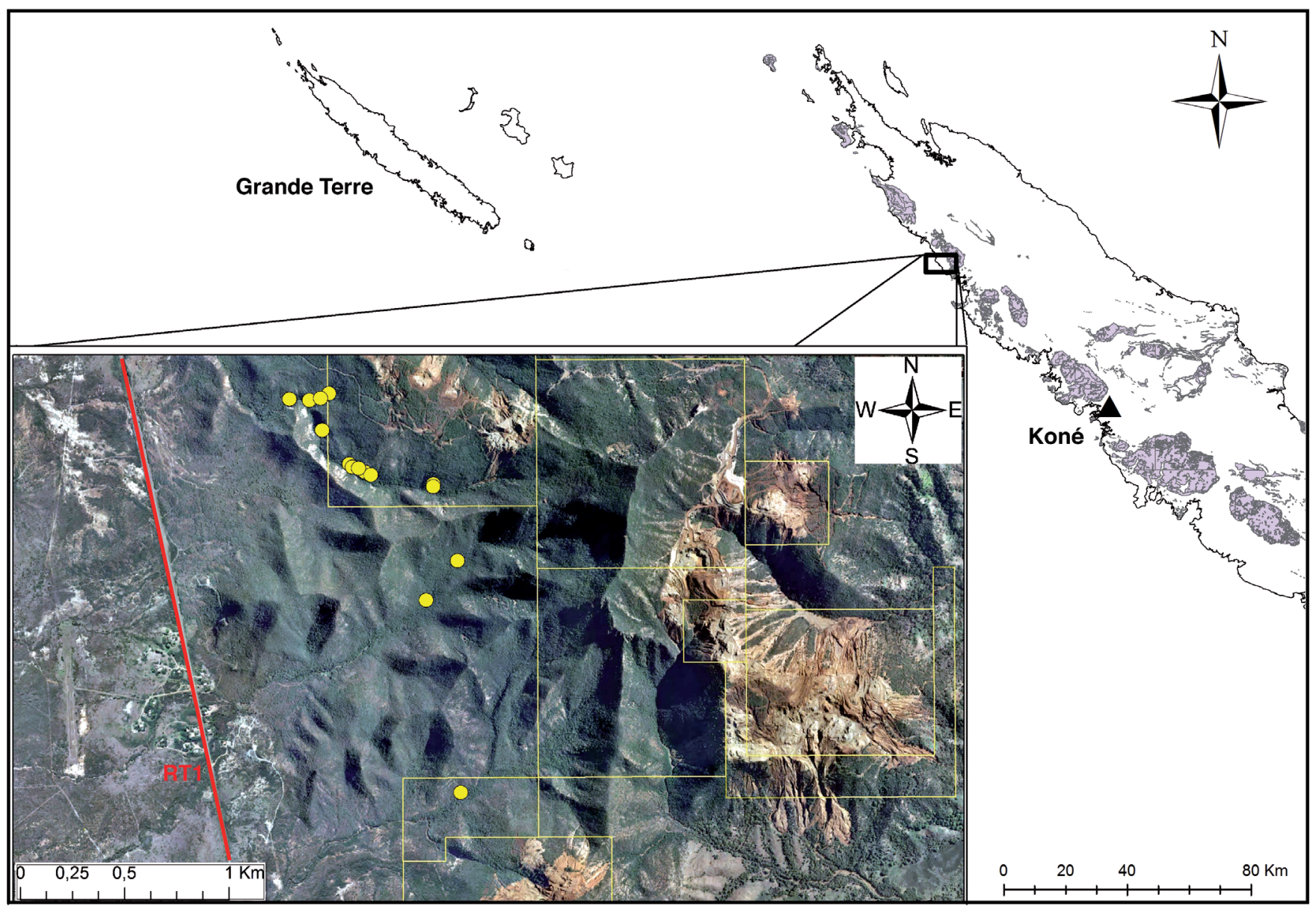

Fig. 2. - Distribution map of subpopulations of Eugenia plurinervia N. Snow, Munzinger \& Callm. (yellow dots) in an area adjacent to mining concession and RT1 road (red) in north-western New Caledonia. Areas in pink and gray indicate ultramafic substrates on Grande Terre. [C Image and mining cadastre from D.I.T.T.T./S.G.T. Governement of New Caledonia]

(2012). This region is outside any protected areas and all individuals are included in, or are adjacent to, a mining concession (Fig. 2). The main threats are anthropogenic fires, which are common in this area, especially starting from the RT1 main road, and future mining activities in the concession. The new species should not be directly threatened by the clearing of vegetation for underground mining (it grows on hyper-magnesium soils that have no mining value), but the area soon could be affected by extensions of mining activity or the clearing of vegetation for road access. Eugenia plurinervia is therefore assigned a preliminarily conservation status of "Critically Endangered" [CR $\mathrm{A} 3 \mathrm{c}+\mathrm{B} 1 \mathrm{ab}(\mathrm{iii}, \mathrm{iv}, \mathrm{v})+\mathrm{B} 2 \mathrm{ab}(\mathrm{iii}, \mathrm{iv}, \mathrm{v})$ ] following IUCN Red List Categories and Criteria (IUCN, 2012).
Notes. - Eugenia plurinervia is one of c. 10-12 congenerics in New Caledonia with relatively small flowers and relatively short leaves ( $<3 \mathrm{~cm}$ long). Although the species boundaries of this group remain under active study by the authors and are not fully resolved, E. plurinervia is unmistakable in Eugenia by the palmately-spreading secondary nerves visible on the upper leaf surface (which are less prominent in dried material), the small white flowers, and the densely punctate leaf blades. Several dozen digital images of living material contributed to the description above, and all indicated colors are based on living material. The mature fruit is said to have a pleasant smell and good taste.

Sterile specimens of E. plurinervia might be confused with Syzygium tenuiflorum Brongn. \& Gris or S. brevipes (Brongn. \& Gris) J.W. Dawson, but those two species each have prominently quadrangular, winged branchlets and cymose inflorescences (DAwson, 1999). 
Paratypi. - New Caledonia. Prov. Nord: Ouazangou-Taom, Onajiele, 2046’31”S 164²7'51”E, 19.III.2016, Munzinger (leg. Scopetra) 7532 (G [G00341660], KSP [KSP010453], MO, MPU [MPU310531], NOU [NOU054445], NSW, P [P01069421]); ibid. loc., 2046’32”S 164²7'50”E, 20.III.2016, Munzinger (leg. Scopetra) 7534, (KSP [KSP010452], MO, MPU [MPU310533], NOU [NOU054447], P [P01069422]); ibid. loc., 2046'42”S 164²7’58”E, 20.III.2016, Munzinger (leg. Scopetra) 7536 (G [G00341661], KSP [KSP010454], MO, MPU [MPU310534], NOU [NOU054446], P [P01069423]); ibid. loc., 2046’30”S 164²7’53”E, 19.III.2016, Munzinger (leg. Scopetra) 7538 (MO, MPU [MPU310535], P [P01069424]); ibid. loc., same date, Munzinger (leg. Scopetra) 7540 (KSP [KSP010450]).

\section{Acknowledgments}

We thank Rosa Scopetra who discovered the species, for the excellent digital images taken in the field, and for collecting invaluable living material and information for our analysis. We also thank Marcos Sobral for reviewing the paper.

\section{References}

Dawson, J.W. (1999). Myrtaceae - Myrtoideae I: Syzygium: In: Morat P. (ed.), Fl. Nouvelle-Calédonie et Dépendances. Muséum national d'Histoire naturelle, Paris.

Ibanez, T., J. Munzinger, G. Dagostini, V. Hequet, F. Rigault, T. JafFré \& P. Birnbaum (2014). Structural and floristic diversity of mixed tropical rain forest in New Caledonia : new data from the New Caledonian Plant Inventory and Permanent Plot Network (NC-PIPPN). Appl. Veg. Sci. 17: 386-397.

IUCN (2012). IUCN Red List Categories and Criteria: version 3.1. $2^{\text {nd }}$ ed. IUCN Species Survival Commission, Gland \& Cambridge.

Jaffré, T., F. Rigault \& J. Munzinger (2012). La végétation. In: Bonvallot J., J.-C. Gay \& E. Habert (ed.), Atlas de la NouvelleCalédonie: 77-80. IRD, Nouméa.

Morat, P., T. Jaffré, F. Tronchet, J. Munzinger, Y. Pillon, J.-M. Veillon \& M. Chalopin (2012). Le référentiel taxonomique Florical et les caractéristiques de la flore vasculaire indigène de la Nouvelle-Calédonie. Adansonia ser. 3, 34: 179-221.

Snow, N., J.W. Dawson, M.W. Callmander, K. Gandhi \& J. Munzinger (2016). New species, new combinations, and lectotypifications in New Caledonian Eugenia L. (Myrtaceae). Candollea 71 : 67-81. DOI: http://dx.doi.org/10.15553/ c2016v711a9 